\title{
BUSINESSES HAVE HUMAN RIGHTS, TOO
}

\section{Petra Butler*}

This article is a verbatim reproduction of my professorial inaugural lecture, delivered on 23 July 2019. ${ }^{1}$ The lecture included visual images and an audio recording that cannot be reproduced here. ${ }^{2}$

Vice Chancellor, Dean, members of the judiciary, colleagues from the Faculty, the University, the legal profession, friends, Conor, Cillian, Clara and my mother and family at the other end of the world, and everyone who came tonight - I am honoured that you have come to share my inaugural lecture with me.

I would like to start this lecture with a story: imagine a court room - the trial a brutal rape. The trial is about to begin when the door opens and in walks a father with his about six-year-old son. The prosecutor and defence lawyer in unison draw a deep breath and are exasperated; they approach the bench and ask the presiding judge to use the court's authority and to remove the young boy from the public gallery since the matter on trial is nothing a young child should ever hear. The presiding judge smiles and refuses and the trial goes ahead. I will come back to the story at the end of the lecture -

* Professor, Victoria University of Wellington.

1 The text was edited occasionally for the ease of reading. Please refer to the following academic articles and chapters discussing different aspects of the research: Petra Butler and Campbell Herbert "Access To Justice vs Access To Justice For Small And Medium-Sized Enterprises: The Case For A Bilateral Arbitration Treaty" 26 (2014) NZULR 186; Petra Butler "40 Years Convention on the International Sale of Goods (CISG) - Even More Important Today than 40 Years Ago to Encourage Trade?" 118 (2019) ZVglRWiss 231; Petra Butler and Christina Geissler "Contractual Realities of SMEs - Access to Commercial Justice" [2020] Austrian Yearbook on International Arbitration (forthcoming); Petra Butler and Georgia Whelan "Does the dispute resolution regime in Europe really serve MSMEs?" in Nikos Lavranos and Jose Rafael Dona Mata (eds) International Arbitration and EU Law (Edward Elgar, Cheltenham (UK)) (forthcoming); and Petra Butler and Hanneke van Oeveren SMEs and International Commercial Dispute Resolution: Without leading the horse to water, it's unlikely that it will drink (UNCITRAL) (forthcoming).

2 The Vice-Chancellor of the University, Professor Grant Guilford, introduced the lecture and the Dean of the Faculty of Law, Dr Mark Hickford, delivered the vote of thanks; their texts are not reproduced here. The lecture is available at: Victoria University of Wellington "Inaugural lecture - Professor Petra Butler" (27 August 2019) <www.youtube.com> 
and even though I would like you to follow my research journey - maybe you can slightly multi-task and think about why the little boy was allowed to stay.

One question an inaugural lecture should answer is, what drives the scholar's research?

The question to my motivation why I became an academic is quickly answered and is a confession - I am an addict! I am an addict to learning, and how to better feed that addiction than staying at university and becoming an academic?

To answer the second part of the why - why my research interest lies in human rights and in international commercial law - I have to transport you back to the cold war and a city, called Braunschweig, $25 \mathrm{~km}$ west of the former iron curtain. A city where, according to probably urban myth, it would have taken "the Russians" 20 minutes to have their tanks positioned in the middle of the city. It was a city where when I went to primary school we, instead of earth quake drills, had air raid drills but most importantly where due to a high fence, soldiers, dogs and mines the world stopped. I struck up a pen pal friendship when I was about 10 with a distant cousin my age at the other side of that impenetrable curtain. Her letters described the restrictions under which she was living: her brother not being allowed to study for political reasons, the inability to leave East Germany even for a holiday. So, in my mind, also fuelled by the then available media and adult conversations around me, my cousin's existence was very bleak.

When I was about 14, I visited. You have to take my word for it that to get to my cousin was complicated: from getting the visa to the border formalities... However, what a surprise - the land behind the barbed wire, the mines and the border guards was not a lot different from where I was from: framework houses, gardens where the fruit trees were laden with fruit, BBQs and children playing soccer. One of my most vivid memories of that visit is the cherry stone spitting competition after lunch. The visit behind the iron curtain taught me three things:

(1) How important it is to challenge generally held views but also one's own assumptions and perceptions

(2) That things are seldom black and white but very grey

(3) And most importantly - that limits to one's humanity can be invisible but must be made visible - that this is an obligation!

This leaves the question why I am interested in international commercial law. In contrast to my cousin I grew up in a family that could and did travel extensively and whose house was like the United Nations: where visitors from all around the world sat at the dinner table. This experience was coupled and contrasted with the fact that I grew up in an area with 14 per cent unemployment (unsurprisingly Talking Heads - The Road to Nowhere - was our school leaving theme song) and instilled the desire in me to understand the mechanisms how other countries tackle their problems and in particular how to generate employment. It also amplified for me from very early on the symbiotic relationship between business and human rights. 
In the following I would like to explore one aspect of the symbiotic relationship between human rights and business: the need for micro, small and medium sized enterprises or SMEs to be able to fully utilise their right to access to cross-border commercial justice so that we can enjoy our human rights.

The research underlying this exploration is not mine alone - it is the result of qualitative and quantitative empirical research, an interdisciplinary endeavour, a collaboration between practice and academia and an international research alliance. I would like to thank and acknowledge everyone who has been part of this research venture - and I am delighted that some of those are here today tonight. ${ }^{3}$

\section{INTRODUCTION}

SMEs, such as the Ethiopian and New Zealand apiarists in the photos, are the predominant business form globally. About 97 to 99 per cent of enterprises in any country or trading block are classified as SMEs. There is agreement among states, business councils, international organisations and academics that SMEs are vital for economic growth. As the OECD representatively has emphasised:"[s]mall and medium sized enterprises are important for their contribution to employment, innovation, economic growth and diversity." Especially, for developing countries, to promote SMEs is a winning strategy - SMEs decentralise the wealth more equitably compared to the large industries. In Ethiopia SMEs provide especially women with a source of income. In New Zealand SMEs employ 30 per cent of the workforce and contribute 28 per cent of the GDP.

Due to their contribution to the economy and economic growth, SMEs play an important role in poverty reduction. And poverty is not only deprivation of economic or material resources but a

3 I am indebted for the encouragement, collegiality, and the assistance I have received in relation to the access to cross-border commercial justice for SMEs research project from Hanneke van Oeveren who breathed life into the project with her thesis: "'It hurts my head to think about it' - SMEs and the Legal Framework for International Commercial Contracts" (LLB (Hons) Dissertation, Victoria University of Wellington, 2016); Georgia Whelan who contributed to the research project's scholarship with her thesis: "Could a BAT Fly? An Evaluation of the Proposed Bilateral Arbitration Treaty in the New Zealand Context" (LLB (Hons) Dissertation, Victoria University of Wellington, 2016) and assisted greatly in conducting the New Zealand qualitative empirical research; Campbell Herbert my co-author of the first article on the research project: "Access To Justice vs Access To Justice For Small And Medium-Sized Enterprises: The Case For A Bilateral Arbitration Treaty", above n 1; Chris Nixon, Institute of Economic Research, who provided the much needed statistical and economic background; Julie Nind, Ministry of Business, Innovation and Employment, whose challenging questions have been a source of inspiration; Gary Born, whose proposed Bilateral Arbitration Treaty regime has provided the background for the research; Wilmer Hale Cutler Pickering Hale and Dorr LLP which hosted me as scholar-in-residence allowing me to pursue the research project in Europe; and my colleagues Gedion Ali, Bahir Dar University; Professor Nadja Alexander, Singapore Management University; Professor Anthony Daimsis, University of Ottawa; Christine Geissler, University of Linz; Professor Eva Lein, British Institute of International and Comparative Law; Jose Mata Dona, barrister (Brussels); Anne McNaughton, Australian National University; Professor Alberto Muñoz Fernández, Universidad de Navarra; Professor Travis Ng, Chinese University of Hong Kong; and Professor Cayetana Santaolalla, University of Mondragón. 
violation of human dignity, fairness and equality. Indeed, no social phenomenon is as comprehensive in its assault on human rights as poverty. Poverty erodes or nullifies economic and social rights such as the right to health, adequate housing, food and safe water and the right to education. It erodes civil and political rights, too, such as the right to a fair trial, political participation and security of the person.

Can SMES in turn have human rights that need protecting? The answer to that is "yes - they can" and the reason is twofold: firstly because the New Zealand Bill of Rights Act 1990 says so (the New Zealand Bill of Rights Act is not alone the European Convention on Human Rights says to, too, for example); and secondly because today we impose state like responsibilities on businesses to uphold human rights in all countries where they operate, and to be very clear, I am a vivid advocate of businesses' responsibility to safeguard human rights - however, with responsibilities come rights. The obvious caveat is that some human rights protect our humanness and are not applicable to businesses.

Like civil society SMEs will struggle to thrive, without the rules and standards that hold public and private powers accountable.

Freedoms, such as the freedom of expression or association, and the right to access to justice allow citizens to expose abuses related to corruption, public health, toxic pollution and gender discrimination. These rights support stable, predictable legal and regulatory environments. At the same time, they enable the free flow of information, investment and entrepreneurial innovation. When these freedoms are undermined, businesses and civil society alike are subject to the law of the jungle instead of the rule of law.

The right at the centre of this lecture is the right to access to justice.

I will first briefly explain what the right to access to justice entails and then explain why it is violated in the case of SMEs trading across borders before proposing a solution.

The right to access to justice in the jurisprudence of courts and human rights tribunals around the world encompasses not only the right to access to the courts but also the right to effective justice, that means a dispute resolution mechanism that is cost-efficient, timely, neutral and provides an expert solution of a dispute. The right to effective justice is a cornerstone of the rights framework because respect and protection of human rights can only be guaranteed by the availability of effective remedies. The right is an essential component of the rule of law and is embedded in the New Zealand Bill of Rights Act in the right to natural justice.

Why is this right to access to effective justice particularly important in the cross-border trade context?

It is uncontroversial among economists that the growth of today's economies is highly dependent on international trade. The expansion into international markets is critical for SMEs' continued growth, and hence for the economy's wellbeing, poverty reduction, and therefore ultimately to protect, defend and to maintain our human rights. However, only 38 per cent of New Zealand's SMEs currently 
export their products and the majority are not interested in generating overseas income. New Zealand SMEs are thereby more adventurous than many of their overseas counterparts: only six per cent of United Kingdom SMEs trade cross border.

One of the reasons for the limited foray into foreign markets by SMEs is the risk associated with doing so. The most commonly cited barrier for New Zealand SMEs is limited experience. The OECD study into barriers of SMEs in regard to conducting international business similarly found limited firm resources, international contacts as well as lack of requisite managerial knowledge about internationalisation to be critical constraints to SME trading cross border.

Embedded in the resource, experience and knowledge barrier is the risk associated with potential cross-border dispute resolution whereby SMEs are not confident that they will be provided with effective commercial justice should a cross-border dispute arise.

The European Commission's study into intra-EU trade by SMEs found that one third of respondents felt that the unknown resolution of cross-border conflicts stifled their cross-border trade. The World Bank/IMF reported that efficiency and transparency in dispute resolution were pivotal in encouraging trade cross-border. In other words, research suggests that SMEs perceive that their right to access to cross-border commercial justice is not guaranteed.

\section{THE STATUS QUO}

Is that perception correct? Is the right to cross-border commercial justice limited for SMEs? Let us have a look at the current cross-border commercial dispute resolution regime available to SMEs.

To date SMEs which engage in cross-border trade are free to agree in front of which country's court they want to get their dispute heard or to means of dispute resolution outside any country's court system, such as international arbitration or mediation. However, qualitative and quantitative research conducted in New Zealand and by my research partners found that SMEs generally lack the knowledge, inclination, resources or bargaining power to incorporate either a favorable jurisdiction clause, i.e. agree to their dispute being heard in a court of their choice - normally their own, or alternative dispute resolution processes, such as arbitration or mediation, into their contracts.

If parties do not agree to a particular dispute resolution mechanism, international trade between private parties operates under a default dispute resolution system of international litigation - that means the dispute will be heard by a court determined by particular applicable rules. And herein lies the issue.

It is generally accepted that international litigation in its current form does not provide a $21 \mathrm{st}$ century response to the needs of parties in the case of cross-border commercial disputes. Or to put it in another way: that default cross-border litigation does violate the SMEs' right to access to an effective dispute resolution mechanism, i.e. a cost-efficient, timely, neutral and expert solution of a dispute. 
So, what is wrong with the current default mechanism of cross-border litigation? Let's start with an example: ${ }^{4}$ Nelson Honey in 2015 found itself in a dilemma - it had contracted with a Singaporean distributor for sale of Manuka honey to China Manuka - but did not have a written contract. When the honey arrived in Shanghai the Singaporean distributor found that the Manuka honey had not the expected colour and refused to take delivery of the honey. Nelson Honey firmly of the view that its honey didn't leave anything to be desired for, unsurprisingly, wanted the purchase price and sued the Singaporean distributor in the High Court in Nelson for the same. The Singaporean distributor in the meantime sued Nelson Honey in the High Court in Singapore for the delivery of a new batch of Manuka honey. Both Courts decided that they had jurisdiction, that means they found they were the right court to hear the case. So, you are looking at parallel court proceedings, for both companies an extra set of lawyers, laws that they are not familiar with and potentially two diametrically opposed court judgments which would lead to another ten years in the courts trying to enforce those judgments. The costs are enormous the outcome uncertain -and Nelson Honey was lucky since Singapore shares the Commonwealth and common law history with New Zealand - laws are different but not too unfamiliar and English is the common language - so this was nearly best-case scenario. However, the fact that there are no final judgments strongly suggests that Nelson Honey and the Singaporean distributor in light of the uncertainties and costs of the parallel proceedings settled their dispute.

Lawyers describe the deficiencies of international litigation as six-fold:

(1) Lack of Neutrality: Commercial parties frequently doubt that national courts, particularly the courts of the home jurisdiction of their counter-party, will render an unbiased and competent decision.

(2) Lack of Experience and Expertise: Very few, if any, national courts can consistently provide the specialised expertise appropriate for commercial disputes which not only have a foreign element but might be in addition also commercially and factually complex

(3) Risk of Parallel or Multiple Litigation: In practice, as the Nelson Honey example demonstrates, cross-border disputes often lead to litigation in multiple fora. The complexity of handling a multiplicity of proceedings is compounded by the inevitable risk of conflicting decisions.

(4) Cost and Time to Resolve Disputes: The very real risk of multiple parallel proceedings in cross-border disputes also leads to prohibitive costs and delays. Parties often have to "layer" counsel, first engaging local counsel and then appointing foreign counsel in each of the various relevant jurisdictions. Moreover, enforcement of judgments often requires multiple sets of lawyers in different jurisdictions. In many cases, litigation is slow, with proceedings taking many years (or more) to conclude, and then being subject to even lengthier delays for appellate review, followed by yet further delays for enforcement.

4 Nelson Honey \& Marketing (NZ) Ltd v William Jacks \& Co (Singapore) Private Ltd [2015] NZHC 1215; and William Jacks \& Co (Singapore)Private Ltd v Nelson Honey \& Marketing (NZ) Ltd [2015] SGHRC 21. 
(5) Obstacles to Enforceability of Judgments: Different jurisdictions apply different rules when enforcing foreign judgments. Assuming the parties obtain a judgment from a national court, it is often difficult or impossible for the judgment to be enforced abroad.

(6) Uncertainty and Unpredictability: The factors outlined above introduce a significant degree of uncertainty and unpredictability, which the parties have little means to influence.

In summary, the current form of cross-border litigation does not meet the requirements of a neutral, efficient and fair dispute resolution process that is legally enforceable. The deficiencies of cross-border litigation have been acknowledged by and have been the focus of the Hague Conference, an international body, which just this month adopted a Convention which aims to make the enforcement of judgments easier. However, given the status of its sibling's Convention which was adopted 12 years ago, and which was the first step in ameliorating the ills of cross-border litigation on the international plane, nothing will change for SMEs soon.

\section{THE PROBLEM}

\section{A Introduction}

The unsatisfactory solution for many SMEs seems to be to "self-hedge", restricting their crossborder trade, thereby restricting the potential growth and benefits such trade could generate. Alternatively, SMEs potentially expose themselves to the serious risks of cross-border litigation, often resulting in unfair and catastrophic results for small enterprises.

This is why we interviewed SMEs in New Zealand and abroad, to find out how SMEs negotiate and conclude cross-border contracts, and how they manage their dispute resolution risks to then be able to propose a solution.

\section{B The Studies}

The New Zealand study interviewed 48 SMEs from manufacturing, to agricultural products, to IT located around the country. The study also interviewed four large companies from different sectors located in different parts of the country. This research is supplemented with available research from the international research alliance which allows for a global insight into MSME contractual behaviour.

I would like to share with you three of the findings of the global research:

(1) The lack of a single contract document.

(2) The lack of awareness of legal issues and lack of engagement of/with legal services.

(3) (Perceived) ingenuity of SMEs.

\section{Lack of a single contract document}

The New Zealand and Spanish studies found that many SMEs do not have one single contract document. Contracting is done in a piecemeal fashion frequently through a mixture of emails, phone calls and even WhatsApp or WeChat. Order forms, export documentation, or bill of ladings are often 
the most comprehensive one single document of the contract but over 50 per cent of SMEs are not even using order forms, bill of ladings or letters of credit the research found. However, the more complex the product, eg the product contains intellectual property rights, or involves distribution agreements, the more likely it is that a single all-encompassing contract document exists. Whether there is a "need" for a formal contract document might also depend on in which country the contractual partner is located - nearly 100 per cent of Austrian SMEs have a single contract document - what lawyers would consider a "proper contract".

New Zealand SMEs expressed a general mistrust of contractual documents. There was some reluctance to require contractual counterparts to sign legalistic-looking documents, perceived as using verbose clauses to contemplate everything that has the potential to go wrong with a particular transaction. The importance of maintaining a relationship between the parties substituted for any written contract. As one participant emphasised:

Good relationships are important to me; I am not really interested in doing deals just for the sake of a deal

... I would much rather work on relationships than signing documents and working at a level of distrust.

Interestingly, even one of the large businesses interviewed stated that contract documents (which contained a choice of law and dispute resolution clause) were just springboards for negotiations and were not really relied upon - they were kept in the bottom draw....

\section{Lack of awareness of legal issue and lack of engagement of/with legal services}

SMEs globally lack resources to engage legal advice or to deal with the associated processes on top of the day job of trying to sustain and to grow their business. In addition, SMEs generally lack awareness of the complexity of the potential legal issues - illustrated by the comment of one of the New Zealand participants:

If someone comes to us to do business, then I guess my gut feeling would be that whatever law we work

in always applies. So, if somebody rings me from the US and wants to buy something from me then I

assume that they came to us, so our law must apply. The moment we call them instead, then US law might apply.

And this SME is not alone - in a contract between an Australian and Italian SME the parties agreed that when the Italian buyer would not pay the purchase price the Australian seller would be able to sue the buyer in Australia under Australian law and vice versa: if the goods were not conforming with the contract the Italian buyer would sue the Australian seller in the Italian courts under Italian law. Even though that seems a common sense approach, legally it is a nightmare.

SMEs are often not aware that in cross-border contracting additional issues might arise which is evidenced by the fact that over 50 per cent of businesses never engage a lawyer when negotiating a contract or when a dispute arises. 
Another "down-to-earth" dispute risk management approach was - my favourite one - echoing perceptions maybe gained by watching a United States legal drama:

No ... because America you know, don't kid yourself. The Americans are not going to sue me, I could

poison and kill an American [with my product] and they wouldn't sue me because the lawyers would not make enough. They could take me to the cleaners, they could take my business, they could take my wife and children and sell them into slavery and they still would not make enough to pay their fee.

Furthermore, in relation to international matters, a SME's usual lawyer might not have a broad knowledge of the best practice for key clauses in an international commercial contract. This may be particularly true for smaller firms located in regional areas of New Zealand with lawyers who engage in a broad range of legal services for both private and commercial clients. Many small businesses will customarily refer all their legal queries and issues to the same lawyer. When asked about the use of drafted documents for international transactions, one participant reported that:

I wouldn't have a clue where to start and I also probably would fear that if I went to my usual lawyer he wouldn't have a clue either...

\section{3 (Perceived) ingenuity of SMEs}

An interesting slightly counter-implication of the multi-tasking SME management is their involvement with, and understanding of the day-to-day performance of contracts, as well as the negotiation thereof. In general, smaller businesses will also have fewer customers and fewer individual transactions than larger firms. Where a firm has fewer customers and fewer transactions, it is possible for the management to "hold the reins" and be personally in control and assess the risk of individual transactions. Smaller businesses may hereby have an increased ability to be selective in whom they deal with and operate on the basis of relationships rather than formal procedures. All 48 participants of the New Zealand study stressed that "trust" was the essential element of their business relationship.

When asked whether documents for sale to a distributor included anything about dispute resolution or applicable law, one participant said:

No ... Eventually we will have to go there but at the moment the relationships are really personal, and I

deal personally with all these people, and when you're sitting across the table face-to-face you work it out.

Since "trust" is the core ingredient of the business relationship SMEs globally spend a considerable amount of time and energy of finding out about their potential contractual partner, including to travel to meet the potential new contract partner and asking around within the industry whether the potential partner is reliable. As a New Zealand participant explains:

There's a number of things we do. We start a dialogue with people. We talk to others who they know in that market about them. We may use [NZTE] to look and see whether they're legitimate or not.

This is echoed by a Singaporean SME in the whole sale trading business: 
We do the checks on buyers. We visit them at least once and know them well.

\section{Concluding observations}

The study so far has revealed that the extent of the SMEs' lack of, what lawyers would call, legal sophistication, when it comes to contracting cross-border and the lack of resources are generally underestimated. Allocation both in time and energy to the various tasks and responsibilities a SME management must perform means that often even awareness of a potential legal risks is not raised neither is information sought, should awareness be present, regarding even relatively simple, let alone complex, legal issues. Some SMEs interviewed for this study had lucky escapes - they were either able to settle their disputes either before or during a cross-border litigation or they were able to walk away from the business relationship without losing their business only to never trade with a business from that country again. Others were vary making a foray into foreign markets, for over 50 per cent of New Zealand and Austrian SMEs dispute resolution concerns were an issue when venturing into a foreign market - this corroborates the findings of the World Bank/IMF and European Commission studies - or they spent considerable time and money into finding out about their prospective foreign business partner.

\section{THE PROPOSED SOLUTION}

Any proposed solution should not only ameliorate the pitfalls of cross-border litigation, most fully vindicate the SMEs' right to access to effective commercial cross-border justice, but also consider and honour the cornerstones of SME contracting: firstly, that the contractual relationship is built on trust over documents and that negotiation is always the first attempt to resolve a dispute. It also needs to consider the nature of SMEs contracting - the lack of awareness of the cross-border dispute resolution risks, their lack of bargaining power, the lack of time and awareness to seek information or to be educated - over two-thirds of SMEs do not use the services of Chamber of Commerce.

What is needed is a new default cross-border dispute resolution system, a system that automatically is applicable if a SME has not put its mind to the dispute resolution risk and cannot negotiate a solution but that also has some attraction to the larger foreign business partner of the SMEs. One dispute resolution regime which holds some promise tackling most of the ills of crossborder litigation is international arbitration.

Arbitration is a dispute resolution regime whereby the parties in dispute agree on another individual in their private capacity or even a tribunal of three or more, to make a final and binding determination regarding the disputed matter. The adjudicators do not have to be lawyers. The parties are free to agree on how the arbitration is to be conducted. International arbitration has been used for over 2000 years, however, has gained favour among especially multinationals in the last 30 years.

How does international arbitration fare against the six issues that make cross-border litigation unsuitable to provide an effective cross-border commercial dispute resolution mechanism? 
(1) Neutrality: Since the parties are free to choose the person or persons adjudicating the disputes the parties can ensure neutrality.

(2) Lack of Experience and Expertise: Again, the parties are free to choose the arbitrator who does not need to be a lawyer, hence the parties can ensure that experts hear the dispute, and that is frequently done, for example, in construction arbitration, engineers instead of lawyers are chosen as arbitrators.

(3) Risk of Parallel or Multiple Proceedings: The risk of parallel proceedings is minimal. Courts honour the valid choice of the parties to arbitrate (based in right to freedom of contract) and so will another arbitral tribunal.

(4) Cost and Time to Resolve Disputes: In recent years cost and time have become an issue in international arbitration among multinationals and larger businesses. However, commodity arbitration and maritime arbitrations are good examples for cost efficient and timely arbitrations. Importantly, arbitration does not require a special set of counsel.

(5) Obstacles to Enforceability: In the ability to easily enforce an arbitral award around the world lies one of the greatest advantages of international arbitration. This is due to the New York Convention, in place for the last 60 years and ratified by 160 countries (out of 193). The Convention mandates the enforcement of a foreign arbitral award in a member country.

(6) Uncertainty and Unpredictability: Of course, no system is perfect, however, due to the parties having control over the process, e.g. over the language in which the proceedings should be conducted - and that can be more than one, the time lines and whether witnesses should be heard, proceedings are much more predictable. Importantly, parties can decide where a hearing should be conducted and even to hold a hearing virtually, i.e. to lower the carbon footprint.

How would international arbitration become the default dispute resolution mechanism for SMEs? Cross-border litigation is mandated through national laws that set out when a court has jurisdiction in a case with a foreign party based on comity among sovereign states (the Nelson Honey case is an illustration that comity has its limits). Since every state has sovereignty over its subjects a state could not adopt a law binding subjects of another state to a particular dispute resolution mechanism to the exclusion of the other states' courts.

However, states could agree among themselves to substitute cross-border litigation with international commercial arbitration as the default dispute resolution regime between commercial entities trading between those states. Such agreement would be by way of a treaty between two or more states and is in line with the response to research recently undertaken where stakeholders have expressed enthusiasm for a regional business to business dispute resolution system.

Free Trade Agreements (FTAs) and/or Bilateral Investment Treaties (BITs) own their existence to the desire to foster trade especially among SMEs by lowering regulatory trade barriers, such as tariffs and customs. If they are successful it follows that more trade will result between the businesses of those countries. More cross-border relationships mean more disputes. To include a business to 
business dispute resolution mechanism based on the principles of international arbitration in FTAs and BITs would ensure that not only SMEs have access to an effective cross-border dispute resolution mechanism when taking advantage of the fruits of an FTA or BIT, but it also would eliminate another trade barrier. In the Comprehensive and Progressive Agreement for Trans-Pacific Partnership an attempt in the direction of the proposed solution has been made by obliging the state parties to the maximum extent possible to encourage and facilitate the use of arbitration for the settlement of international commercial disputes between private parties.

A dispute mechanism based on the principles of arbitration would be the default dispute resolution mechanism. Parties would of course remain free to opt out of that regime and choose a regime of their choice, including agreeing to settle their dispute in front of a court.

The dispute resolution mechanism would prescribe those factors ordinarily found in a full arbitration agreement: the rules according to which the arbitration is to be conducted, the number of arbitrators and the appointing mechanism. UNCITRAL, the commercial arm of the United Nations, has issued Rules of Arbitration, which represent international best practice and maximum neutrality and therefore would provide an excellent basis.

Default arbitration under a FTA or BIT could ease many of the concerns raised regarding crossborder litigation generally. It would prevent parallel proceedings, provide for expert adjudicators and an easier means of enforcement of any issued award.

The FTA/BIT arbitration regime could also alleviate legal issues that are of particular concern to SMEs and could level the playing field between larger and smaller businesses - to highlight just three of those benefits:

(1) taking account of, when designing the procedure, of the SMEs' contract cornerstones- trust and negotiation - by allowing and encouraging a period of negotiation or mediation;

(2) designing a procedure that takes account of environmental sustainability by allowing for the use of online processes; and

(3) setting out a mandatory cost structure.

However, the proposal raises four counterarguments: the apparent affront to the constitutional guarantee of access to the courts; and related to it an apparent affront against the core constitutional principle of separation of powers; the existence of regimes that already seek to address some of the problems with international litigation; and a fear of the unknown. Those concerns, however, can be diffused.

Firstly, regarding the limitation of the right to access to the courts. Parties will have access to the courts when an award is enforced where the courts hold a certain supervisory power. In addition, it has been argued that the right to access to the courts only encompasses right to access to the national courts which in a cross-border situation does not exist as per right. Most importantly, the right to access to the courts as well as the right to effective justice are both part of the right to access to justice 
and therefore have to be balanced against each other - the right to the courts is meaning less if the courts are not able to provide effective justice where an alternative regime exists.

More heavily ways the proposed regime's violation of the core principle of a modern democratic state: separation of powers. The proposed regime, one could argue, deprives the courts as one of the powers of government of an entire segment of its work, i.e. commercial cases pertaining to a particular geographical area. However, the courts are not getting the cases at the moment either, albeit for different reasons: because as the research has evidenced cross-border litigation is the least favoured dispute resolution mechanism for SMEs and large businesses alike and as Nelson Honey has indicated there might be a competing court. The proposed regime at least would give the courts of the country where enforcement is sought some supervisory power, i.e. courts would retain their power as an arm of the government.

Thirdly, regarding the argument that efforts to ameliorate the deficiencies of cross-border litigation are on the way - so far those have been of limit success.

Fourthly, the fear of the unknown. When New Zealand enacted the accident compensation scheme it was a unique step and a complete step into the unknown, far more unknown what is proposed regarding the FTA/BIT commercial dispute resolution scheme.

In summary, commercial dispute resolution regime based on the principles of international arbitration incorporated in a FTA/BIT will benefit the Ethiopian apiarist as much as New Zealand one. It can ensure that a SME has access to effective justice should it need it. It will remove another barrier to trade for SMEs - one New Zealand SME owner stated that he could not care less about the Trans Pacific Partnership Agreement at the time, but his concern was his potential United States business partners who seem to be reluctant to contract with him for fear of potentially ending up in a New Zealand court.

To reduce poverty and to safeguard our rights we need SMEs globally to trade and to trade crossborder. That means we need to provide them with a framework in which they can access their right to effective cross-border commercial justice.

\section{CONCLUDING REMARKS}

There are two tasks left for me - to tell you the end of the story with which I started - the reason the judge smiled (who was my father) and allowed the boy to listen to the rape trial was because the boy and his family were visiting us and did not speak one word of German. He and his father were just interested how a German criminal trial was conducted and see my father at work. For me the story encapsulates what academia is about - never take what you see as a given, challenge not only your but also everyone else's perception and never easily accept the obvious answer.

I would like to conclude with thanking wholeheartedly the many people who have contributed to me being able to share my research with you today through friendship, collegial support, mentorship, by challenging me - but in particular my parents and Clara, Conor and Cillian. 
